\title{
Collagen Alpha-1(II) Chain
}

National Cancer Institute

\section{Source}

National Cancer Institute. Collagen Alpha-1(II) Chain. NCI Thesaurus. Code C75319.

Collagen alpha-1(II) chain (1487 aa, $142 \mathrm{kDa}$ ) is encoded by the human COL2A1 gene.

This protein plays a role in both cartilage structure and skeletal development. 